\title{
Bullous pemphigoid resembling erythema gyratum repens - case report
}

\section{Pemfigoid pęcherzowy przypominający erythema gyratum repens - opis przypadku}

\author{
Małgorzata P. Dominiak', Sebastian K. Kłosek', Zofia Gerlicz-Kowalczuk², Joanna Krzysiek', \\ Aleksandra Kobusiewicz², Andrzej Kaszuba' \\ 'Department of Dermatology, Paediatric Dermatology and Dermatological Oncology, Medical University of Lodz, Poland
2Department of Psychodermatology, Medical University of Lodz, Poland
}

'Klinika Dermatologii, Dermatologii Dziecięcej i Onkologicznej, Uniwersytet Medyczny w Łodzi, Polska

2Zakład Psychodermatologii, Uniwersytet Medyczny w Łodzi, Polska

Dermatol Rev/Przegl Dermatol 2017, 104, 439-445 DOI: https://doi.org/I0.5I |4/dr.2017.69769

\author{
CORRESPONDING AUTHOR/ \\ ADRES DO KORESPONDENCJI: \\ Małgorzata Dominiak \\ Klinika Dermatologii, \\ Dermatologii Dziecięcej \\ i Onkologicznej \\ Uniwersytet Medyczny w Łodzi \\ ul. Kniaziewicza $1 / 5$ \\ 91-347 Łódź, Polska \\ tel.: +48 697714841 \\ e-mail: dominiakmp@gmail.com
}

\begin{abstract}
Introduction. Bullous pemphigoid is one of the most common autoimmune bullous dermatoses. It is typically diagnosed in elderly patients and can have various clinical presentations. So far, only individual cases of erythema gyratum repens-like bullous pemphigoid have been described in literature worldwide.

Objective. Presentation of the case of a patient with bullae forming a wood grain arrangement.

Case report. A 76-year-old female patient hospitalised at the Department of Dermatology with erythematous and edematous figurate lesions and tense bullae on the trunk and extremities. On direct immunofluorescence, complement deposits at the basement membrane zone were found. BIOCHIP indirect immunofluorescence revealed circulating anti-BP180 IgG antibodies.

Conclusions. In patients with suspected bullous pemphigoid, direct and indirect immunofluorescence assays are required. As part of the diagnosis of both pemphigoid and erythema gyratum repens, malignancy needs to be excluded as a potential cause of skin lesions. In the presented patient, medical history and additional tests did not demonstrate the presence of a neoplasm. The patient requires further clinical follow-up.
\end{abstract}

\section{STRESZCZENIE}

Wprowadzenie. Pemfigoid pęcherzowy należy do najczęstszych autoimmunizacyjnych dermatoz pęcherzowych. Zazwyczaj występuje u osób w wieku starszym, może mieć różne odmiany kliniczne. W piśmiennictwie opisano dotychczas jedynie kilka przypadków pemfigoidu pęcherzowego o morfologii erythema gyratum repens.

Cel pracy. Przedstawienie przypadku pacjentki, u której zmiany skórne miały postać pęcherzy układających się na wzór słojów drzewa.

Opis przypadku. Kobieta w wieku 76 lat, hospitalizowana na oddziale dermatologii z powodu obrączkowatych zmian rumieniowo-obrzękowych oraz pęcherzy o napiętej pokrywie na tułowiu i kończynach. 
W immunofluorescencji bezpośredniej wykryto złogi dopełniacza wzdłuż błony podstawnej. W immunofluorescencji pośredniej metodą BIOCHIP stwierdzono obecność krążących IgG przeciwko antygenowi BP180.

Wnioski. W przypadku podejrzenia pemfigoidu pęcherzowego konieczne są badania metodą immunofluorescencji pośredniej i bezpośredniej. Rozpoznanie zarówno pemfigoidu, jak i erythema gyratum repens wymaga wykluczenia procesu złośliwego jako przyczyny zmian skórnych. U opisywanej pacjentki w wywiadzie oraz badaniach dodatkowych nie stwierdzono obecności nowotworu. Wymaga ona dalszej obserwacji klinicznej.

Key words: bullous pemphigoid, immunofluorescence, erythema gyratum repens.

Słowa kluczowe: pemfigoid pęcherzowy, immunofluorescencja, erythema gyratum repens.

\section{INTRODUCTION}

Bullous pemphigoid (BP) is a chronic dermatosis caused by an autoimmune reaction against structural proteins of the dermal-epidermal junction [1]. Available studies failed to explain the aetiology of the condition, although in $15 \%$ of cases, a relationship with medications, neoplasms, active psoriasis, exposure to ultraviolet radiation or bacterial and viral infections was demonstrated [2-4]. At the epidemiological level, BP is a major problem in the elderly. The relative risk of disease development in patients aged 90 years is almost 300 times higher than in those aged 60 years [5]. Typically, the clinical picture consists of itching and burning tense bullae filled with serous fluid in the area of erythematous and edematous lesions and on apparently normal skin. Predilection sites include upper extremities, especially on anterior surfaces, anterior surface of the tights and the trunk. Usually, head, neck and mucous membranes remain clear. Various presentations of BP pose diagnostic challenges. $\mathrm{Cu}$ taneous lesions can have the form of erythematous and edematous lesions, urticaria, bullae and vesicles, or they can resemble erythema multiforme [6]. The most common presentations of BP described in literature include: localised/pretibial, bullous / herpetiformis, paraneoplastic, dyshidrosiform, resulting from scratching, drug-induced, urticarial, seborrheic, erythrodermic, vegetans, post-traumatic, nodular/prurigo nodularis-like, erosive and ecthyma gangrenosum-like pemphigoid. The PubMed database contains only individual reports on cases of $\mathrm{BP}$ resembling erythema gyratum repens (EGR, Gammel's disease) [7-10].

\section{WPROWADZENIE}

Pemfigoid pęcherzowy (bullous pemphigoid - BP) jest przewlekłą dermatozą wynikającą z autoimmunizacji wobec białek strukturalnych połączenia skórno-naskórkowego [1]. Dotychczasowe badania nie wyjaśniły przyczyn rozwoju tego schorzenia, chociaż w ok. 15\% przypadków udaje się wykazać związek z lekami, nowotworami, nasiloną łuszczycą, ekspozycją na ultrafiolet lub zakażeniami bakteryjnymi i wirusowymi [2-4]. Epidemiologicznie BP stanowi istotny problem u osób w podeszłym wieku. Ryzyko względne zachorowania w wieku 90 lat jest prawie 300-krotnie większe niż w wieku 60 lat [5]. Zwykle w obrazie klinicznym występują swędzące lub piekące, dobrze napięte pęcherze wypełnione surowiczym płynem w obrębie wykwitów rumieniowo-obrzękowych i na skórze pozornie niezmienionej, zlokalizowane predylekcyjnie na kończynach górnych, zwłaszcza po stronie zgięciowej, na przyśrodkowej powierzchni ud i na tułowiu. Zazwyczaj wolne od zmian są głowa, szyja i błony śluzowe. Trudności diagnostyczne w BP są skutkiem występowania różnych odmian tego schorzenia. Zmiany skórne mogą mieć charakter rumieniowo-obrzękowy, pokrzywkowaty, pęcherzowy i pęcherzykowy czy przypominający rumień wielopostaciowy [6]. Główne opisywane w piśmiennictwie odmiany to: BP klasyczny, zlokalizowany lub przedpiszczelowy, pęcherzykowy lub opryszczkowaty, paraneoplastyczny, potnicowy, z wydrapania, polekowy, pokrzywkowy, łojotokowy, erytrodermiczny, bujający, pourazowy, guzkowy lub przypominający świerzbiączkę guzkową, nadżerkowy i przypominający ecthyma gangrenosum. W PubMed istnieje jedynie kilka opisów przypadków BP o morfologii erythema gyratum repens (EGR, choroba Gammela) [7-10] [6]. 
Diagnostics of bullous pemphigoid should include: clinical picture, histopathological examination (hematoxylin and eosin staining), direct immunofluorescence (DIF) for anti-hemidesmosome antibodies in tissue and tests for circulating autoantibodies, whereas indirect immunofluorescence (IIF) assays for circulating IgG on monkey oesophagus is characterised by superior detectability of autoimmune reactions as compared to ELISA assay for anti-BP180NC16A and/or anti-BP230-C IgG antibodies [11]. Indirect immunofluorescence may involve the use of the BIOCHIP mosaic (as in the presented case), where tissue sections and cell substrates can be positioned side by side on the same reactive field. As a result, it is possible to simultaneously test one sample for antibodies against several substrates, which shortens the testing procedure. The substrates used in the diagnostics of pemphigoid with the method include: monkey oesophagus, primate salt-split skin, and antigen dots of tetrameric BP180NC16A and BP230gC-expressing cells [12].

\section{OBJECTIVE}

This report presents the case of a female patient with BP of rare morphology.

\section{CASE REPORT}

A female 76-year-old patient was admitted to the Department for diagnostics and treatment of multiple erythematous and edematous lesions and bullae localised on the trunk, extremities and neck (Fig. 1), which appeared gradually over a week preceding hospitalisation. The patient did not report the use of any new drugs or contact with chemicals before the onset of skin lesions. The patient was receiving chronic internist therapy for hypertension and dyslipidemia. The chronic therapy consisted of indapamide, amlodipine, acetylsalicylic acid, bisoprolol, potassium chloride and rosuvastatin. Physical examination revealed obesity; otherwise, no significant abnormalities. During hospitalisaton, the lesions evolved into bullae with wood grain arrangement (Figs. 2, 3). Laboratory testing revealed no abnormalities except for increased D-dimer concentration. Tumour markers were normal. No abnormalities were found on additional testing: chest X-rays, abdominal ultrasound, and breast ultrasound. Direct immunofluorescence test of a skin specimen revealed C3 complement deposits at the basement membrane zone. Serum immunofluorescence with the BIOCHIP assay showed: positive IgG titer of $1: 80$ on monkey oesophagus, linear IgG deposits on the artificial blister roof (salt-split skin) and auto-
Rozpoznanie BP powinno uwzględniać: obraz kliniczny, badanie histopatologiczne (barwienie hematoksyliną i eozyną), bezpośrednie badanie immunofluorescencyjne (direct immunofluorescence - DIF) tkanki oraz badania surowicy w kierunku autoprzeciwciał przeciwko antygenom hemidesmosomalnym, przy czym oznaczanie przeciwciał IgG metodą immunofluorescencji pośredniej (indirect immunofluorescence - IIF) na przełyku małpy zwiększa wykrywalność autoimmunizacji w porównaniu z badaniem metodą ELISA IgG wobec BP180NC16A i/lub BP230-C [11]. Immunofluorescencja pośrednia może być przeprowadzana z użyciem tzw. mozaiki BIOCHIP (jak w opisanym przypadku), w której substraty tkankowe i komórkowe umieszczane są obok siebie na tym samym polu reakcyjnym. Dzięki temu możliwe jest jednoczesne badanie jednej próbki w kierunku przeciwciał przeciwko kilku substratom, co skraca procedurę badawczą. W diagnostyce pemfigoidu za pomocą tej metody substratami są: przełyk małpy, split skórny oraz komórki z transfekowanymi antygenami BP230 i BP180 [12].

\section{CEL PRACY}

W niniejszej pracy przedstawiono przypadek kobiety chorej na BP o rzadko obserwowanej morfologii.

\section{OPIS PRZYPADKU}

Pacjentka w wieku lat 76 została przyjęta do kliniki w celu diagnostyki i leczenia licznych zmian rumieniowo-obrzękowych oraz pęcherzy zlokalizowanych na tułowiu, kończynach i szyi (ryc. 1), które pojawiały się stopniowo w ciągu tygodnia poprzedzającego hospitalizacje. W wywiadzie nie podawała zastosowania nowych leków czy kontaktu ze środkami chemicznymi przed pojawieniem się wykwitów skórnych. Chora była przewlekle leczona internistycznie z powodu nadciśnienia tętniczego i dyslipidemii. Przyjmowała na stałe indapamid, amlodypinę, kwas acetylosalicylowy, bisoprolol, chlorek potasu i rozuwastatynę. W ogólnym badaniu fizykalnym stwierdzono otyłość, poza tym bez istotnych odchyleń od normy. W trakcie hospitalizacji zmiany ewoluowały w pęcherze układające się na wzór słojów drzewa (ryc. 2, 3). W badaniach laboratoryjnych nie odnotowano nieprawidłowości poza zwiększonym stężeniem D-dimerów. Markery nowotworowe były w normie. W badaniach dodatkowych - rentgenograficznym (RTG) klatki piersiowej, ultrasonograficznym (USG) jamy brzusznej, USG piersi - nie stwierdzono nieprawidłowości. W badaniu wycinka skóry metodą DIF odnotowano złogi komplementu C3 wzdłuż błony podstawnej. W badaniu immunofluorescencji surowicy przeprowadzonym testem BIOCHIP wykryto na przełyku małpy przeciwciała IgG w mianie 1 : 80, linijne złogi IgG w pokrywie sztucznego pęcherza (split skórny) oraz 


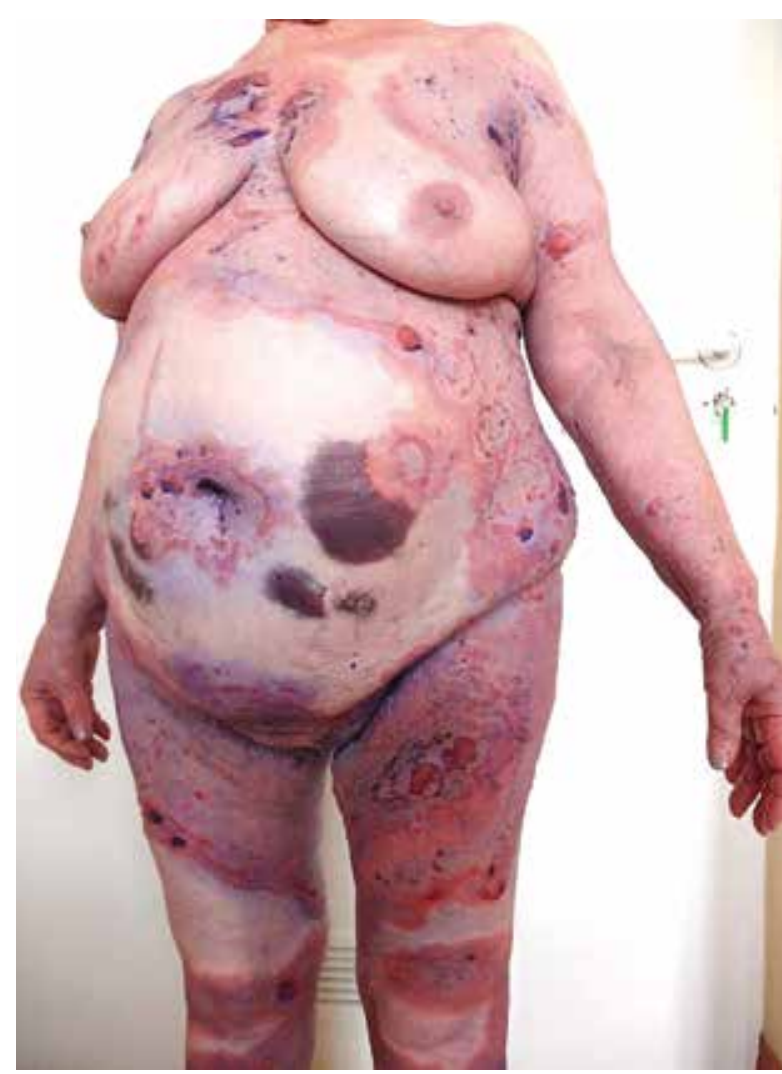

Figure I. Erythematosus lesions and blisters in the course of bullous pemphigoid

Rycina I. Zmiany rumieniowo-obrzękowe oraz pęcherze w przebiegu pemfigoidu pęcherzowego

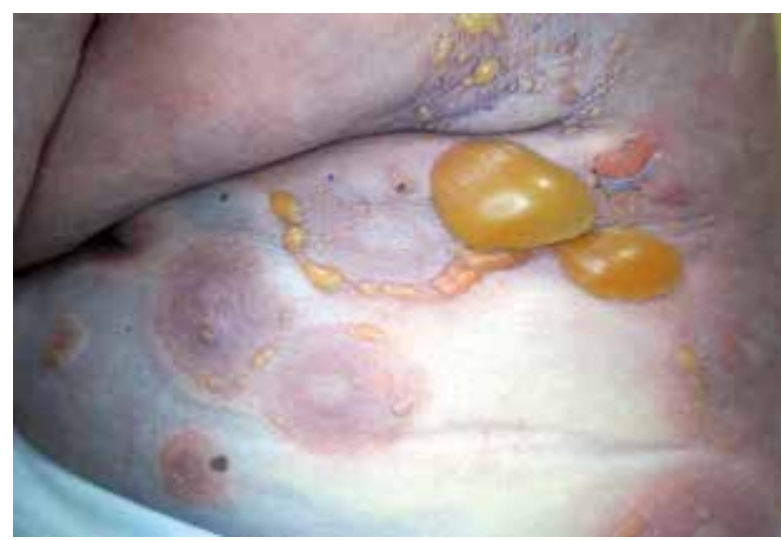

Figure 3. Figurate skin lesions on the trunk in the course of bullous pemphigoid

Rycina 3. Zmiany skórne obrączkowate na tułowiu w przebiegu pemfigoidu pęcherzowego

immune response against BP180. ELISA assay using recombinant NC16A protein was not performed.

Based on the clinical picture and additional tests, the patient was diagnosed with EGR-like BP. At present, clobetasol cream in monotherapy, applied onto the whole body, is the treatment of choice. Al-

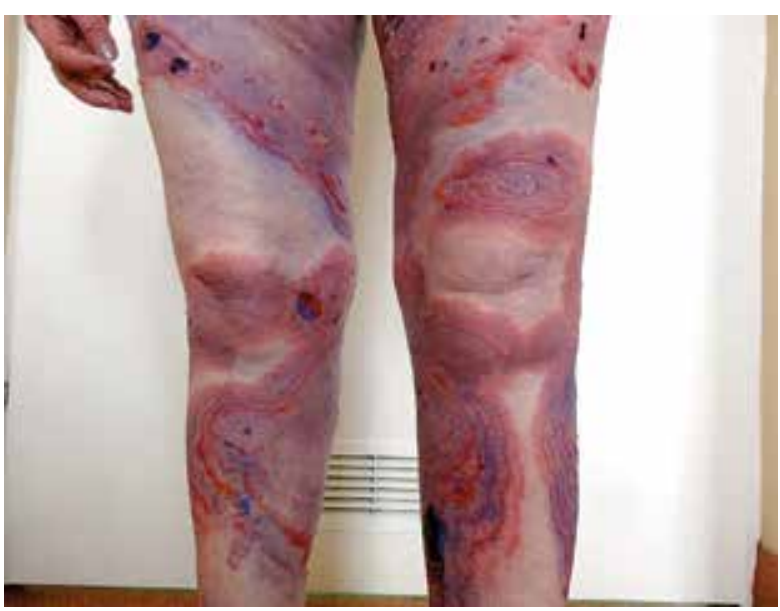

Figure 2. Skin lesions with wood grain arrangement in the course of bullous pemphigoid

Rycina 2. Układające się na wzór słojów drzewa zmiany skórne w przebiegu pemfigoidu pęcherzowego

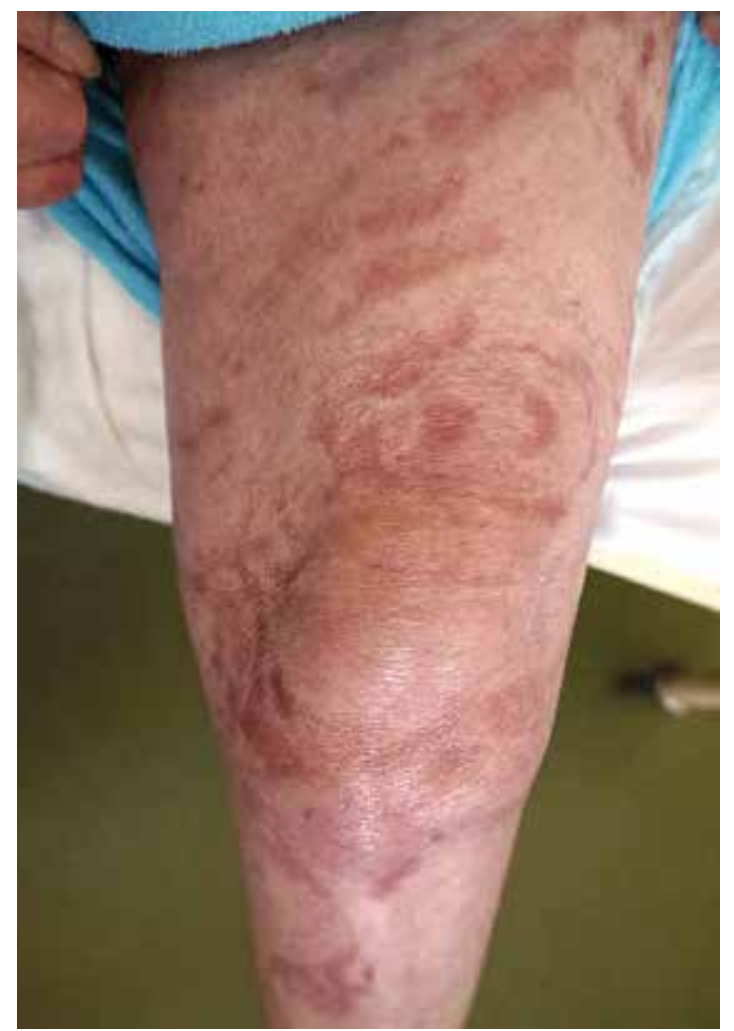

Figure 4. Remission of skin lesions on the leg

Rycina 4. Ustępowanie mykwitów chorobowych na kończynie dolnej

wykazano autoimmunizację wobec BP180. Nie wykonywano badania techniką ELISA z rekombinowanym antygenem NC16A.

Na podstawie obrazu klinicznego i badań dodatkowych rozpoznano BP o morfologii EGR. Obecnie leczeniem $\mathrm{z}$ wyboru BP jest monoterapia klobetazolem w kre- 
ternatives include methotrexate and a combination therapy with tetracycline and vitamin PP [13].

In the discussed patient, antibiotic therapy with tetracycline $250 \mathrm{mg}$ three times a day with vitamin PP was initiated. Due to the extensiveness of skin lesions and severe local complaints, taking into account good general health status of the patient, not only topical glucocorticoids but also systemic immunosuppressant therapy, initially with prednisone $60 \mathrm{mg} /$ day, were administered. During the next week of hospitalisation, due to the continuous appearance of new bullae, methotrexate was added at a weekly dose of $15 \mathrm{mg}$. In addition, $2 \%$ aqueous pyoctanin solution was used topically for erosions. Once improvement in skin lesions was achieved, a gradual prednisone dose titration was started. At a check-up after 2 months, remission of skin lesions was found, with remaining postinflammatory pigmentation (Fig. 4).

\section{DISCUSSION}

Erythema gyratum repens is characterised by quickly expanding concentric erythema with wood grain arrangement [14]. It is a rare disorder, traditionally classified as a cutaneous paraneoplastic syndrome. However, some authors point out that even $30 \%$ of EGR cases may not be associated with co-existing neoplasm [15].

According to literature reports, some other conditions can resemble EGR, including: lepromatous leprosy, limited systemic sclerosis, psoriasis, bullous pemphigoid and bullous systemic lupus erythematosus [16, 17]. The PubMed database contains reports on a few EGR-like BP cases. Gilmour et al. suggest that in the case of pemphigoid of such morphology, association with visceral tumours may be stronger [18]. Graham-Brown also demonstrated tumour in a patient with this type of skin lesions [9]. Individual publications discuss drug-induced [8] or infectious [19] aetiology of erythema. At the same time, Reynoso-von Drateln et al. discuss the presence of concentric bullous lesions in a patient without underlying malignancy or any other detectable cause [7]. In the presented patient, history-taking and additional tests did not indicate a neoplastic cause of the lesions; however, the patient requires further clinical follow-up. As part of the diagnosis of both BP and EGR, malignancy needs to be excluded as a potential cause of skin lesions. Determination of the risk of such a process requires further testing. In patients with bullous lesions of atypical morphology, histopathological examination as well as DIF and IIF assays are required. mie na całą skórę. Alternatywnie zaleca się metotreksat oraz połączenie tetracykliny z witaminą PP [13].

U przedstawionej chorej wdrożono antybiotykoterapię tetracykliną 3 razy po $250 \mathrm{mg} \mathrm{z}$ witaminą $\mathrm{PP}$. Ze względu na znaczną rozległość zmian skórnych i nasilone dolegliwości miejscowe, a także dobry stan ogólny pacjentki, włączono nie tylko miejscowe glikokortykosteroidy, lecz także ogólne leczenie immunosupresyjne - początkowo prednizon w dawce $60 \mathrm{mg}$ / dobę. W kolejnym tygodniu hospitalizacji z powodu dalszego pojawiania się nowych pęcherzy dołączono metotreksat w dawce $15 \mathrm{mg} /$ tydzień. Dodatkowo miejscowo stosowano $2 \%$ wodny roztwór pioktaniny na nadżerki. Po uzyskaniu poprawy w zakresie zmian skórnych rozpoczęto stopniową redukcję dawki prednizonu. W trakcie wizyty kontrolnej po 2 miesiącach stwierdzono ustąpienie zmian skórnych z pozostawieniem przebarwień pozapalnych (ryc. 4).

\section{OMÓWIENIE}

Erythema gyratum repens charakteryzuje się szybko szerzącymi się koncentrycznie rumieniami, których układ przypomina słoje drzewa [14]. Jest to rzadkie schorzenie tradycyjnie zaliczane do skórnych zespołów paraneoplastycznych. Niektórzy autorzy zwracają jednak uwagę, że nawet 30\% przypadków EGR może przebiegać bez współistniejącego nowotworu [15].

Według piśmiennictwa EGR może być imitowany przez inne jednostki chorobowe, w tym postać lepromatyczną trądu, limited systemic sclerosis, łuszczycę, pemfigoid pęcherzowy, toczeń rumieniowaty pęcherzowy [16, 17]. W bazie PubMed istnieje kilka opisów przypadków BP przypominającego EGR. Gilmour i wsp. sugerują, że pemfigoid o tej morfologii może wykazywać silniejszy związek z nowotworami narządów wewnętrznych [18]. Graham-Brown również stwierdził obecność nowotworu u pacjenta ze zmianami skórnymi o tym charakterze [9]. Pojedyncze publikacje przedstawiają polekową [8] lub przyinfekcyjną [19] etiologię wykwitów. Reynoso-von Drateln i wsp. opisują natomiast wysiew pęcherzy o koncentrycznym układzie u pacjenta bez nowotworu i innej uchwytnej przyczyny [7]. U opisywanej pacjentki wywiad oraz badania dodatkowe również nie wykazały podłoża neoplastycznego wykwitów chorobowych; wymaga ona dalszej obserwacji klinicznej. Rozpoznanie zarówno BP, jak i EGR wymaga wykluczenia procesu nowotworowego jako przyczyny zmian skórnych. Do określenia ryzyka rozwoju tego procesu potrzebne są dalsze badania. W przypadku zmian pęcherzowych o nietypowej morfologii konieczne są badanie histopatologiczne oraz badania metodą DIF i IIF. 


\section{CONCLUSIONS}

Diversity of the clinical picture of BP undoubtedly poses a substantial diagnostic challenge for physicians. The presented case of BP evolution from erythematous and edematous lesions to concentric bullae demonstrates the need for a detailed dermatological assessment of non-specific skin lesions and a careful analysis of all available clinical and laboratory data. Diagnostic immunopathology tests are necessary for initiating appropriate immunosuppression.

\section{CONFLICT OF INTEREST}

The authors declare no conflict of interest.

\section{WNIOSKI}

Różnorodność obrazu klinicznego BP stanowi niewątpliwie duże wyzwanie diagnostyczne dla lekarza. Przedstawiony przypadek ewolucji BP od wykwitów rumieniowo-obrzękowych do koncentrycznie układających się pęcherzy wskazuje na konieczność wnikliwej oceny dermatologicznej niecharakterystycznych zmian skórnych oraz rozważnej analizy wszystkich dostępnych danych klinicznych i laboratoryjnych. Przeprowadzenie diagnostyki immunopatologicznej jest podstawą do wdrożenia właściwego leczenia immunosupresyjnego.

\section{KONFLIKT INTERESÓW}

Autorzy deklarują brak konfliktu interesów.

\section{References \\ Piśmiennictwo}

1. Dmochowski M., Bowszyc-Dmochowska M., Gornowicz-Porowska J., Pietkiewicz P.: Autoimmunizacyjne dermatozy pęcherzowe w starości. Spersonalizowane naświetlenie zagadnienia. Dermatol Klin 2014, 16, 25-34.

2. Stavropoulos P.G., Soura E., Antoniou C.: Drug-induced pemphigoid: a review of the literature. J Eur Acad Dermatol Venereol 2014, 28, 1133-1140.

3. Ogawa H., Sakuma M., Morioka S., Kitamura K., Sasai Y., Imamura S., et al.: The incidence of internal malignancies in pemphigus and bullous pemphigoid in Japan. J Dermatol Sci 1995, 9, 136-141.

4. Białynicki-Birula R., Gajdzis P.: Szczepionki jako jeden z czynników wywołujących pemfigoid pęcherzowy. Dermatol Klin 2008, 10, 37-40.

5. Bergler-Czop B., Brzezińska-Wcisło L., Miziołek B.: Pemfigoid pęcherzowy w oddziałach dermatologii województwa śląskiego w latach 2001-2014. Post Nauk Med 2015, 28, 166-172.

6. Jabłońska S., Majewski S.: Choroby pęcherzowe o podłożu immunologicznym. [In:] Choroby skóry i choroby przenoszone drogą płciową. S. Jabłońska, S. Majewski (eds.), PZWL, Warsaw, 2013, 244-247.

7. Reynoso-von Drateln C., Balderrama-Vargas C., Martínez-Baumbach E.B., Tinoco-Ventura E., Rodríguez-Mora E.: Bullous pemphigoid with figurate erythema. A case report. Rev Med Inst Mex Seguro Soc 2008, 46, 427-430.

8. Wozniak K., Kowalewski C., Hashimoto T., Ishii N., Glinska-Wielochowska M., Schwartz R.A.: Penicillin-induced anti-p200 pemphigoid: an unusual morphology. Acta Derm Venereol 2006, 86, 443-446.

9. Graham-Brown R.A.: Bullous pemphigoid with figurate erythema associated with carcinoma of the bronchus. Br J Dermatol 1987, 117, 385-388.

10. Breathnach S.M., Wilkinson J.D., Black M.M.: Erythema gyratum repens-like figurate eruption in bullous pemphigoid. Clin Exp Dermatol 1982, 7, 401-406.

11. Dmochowski M., Bowszyc-Dmochowska M., Gomowicz-Porowska J., Pietkiewicz P.: Choroby pęcherzowe. Pemfigoid pęcherzowy kardynalną kwestią medyczno-społeczną w zakresie autoimmunizacyjnych dermatoz pęcherzowych. [In:] Metody diagnostyczne w dermatologii, wenerologii i mikologii lekarskiej. Z. Adamski, A. Kaszuba (eds.) Czelej, Lublin, 2015, 205-225.

12. Van Beek N., Rentzsch K., Probst C., Komorowski L., Kasperkiewicz M., Fechner K., et al.: Serological diagnosis of autoimmune bullous skin diseases: prospective comparison of the BIOCHIP mosaic-based indirect immunofluorescence technique with the conventional multi-step single test strategy. Orphanet J Rare Dis 2012, 7, 49.

13. Woźniak K., Dmochowski M., Placek W., Waszczykowska E., Żebrowska A., Nowicki R., et al.: Pemfigoid - diagnostyka i leczenie. Konsensus Polskiego Towarzystwa Dermatologicznego. Przegl Dermatol 2016, 103, 19-34.

14. Gammel J.A.: Erythema gyratum repens; skin manifestations in patient with carcinoma of breast. AMA Arch Derm Syphilol $1952,66,494-505$.

15. Rongioletti F., Fausti V., Parodi A.: Erythema gyratum repens is not an obligate paraneoplastic disease: a systematic review of the literature and personal experience. J Eur Acad Dermatol Venereol 2014, 28, 112-115.

16. Mohanan S., Devi A.S., Kumari R., Thappa D.M., Ganesh R.N.: Novel presentation of lepromatous leprosy in an erythema gyratum repens-like pattern. Int J Dermatol 2014, 53, 210-212.

17. Spierings N.M., Natkunarajah J.: Leucocytoclastic vasculitis presenting as an erythema gyratum repens-like eruption. Clin Exp Dermatol 2016, 41, 320-322.

18. Gilmour E., Bhushan M., Griffiths C.E.: Figurate erythema with bullous pemphigoid: a true paraneoplastic phenomenon? Clin Exp Dermatol 1999, 24, 446-448. 
19. Dolenc-Voljc M., Zgavec B., Vizjak A., Tenyi V., Luzar B.: Figurate erythema in a patient with bullous pemphigoid and Toxocara infection. Acta Dermatovenerol Alp Pannonica Adriat 2013, 22, 87-89.

Received: 17.05 .2017

Accepted: 4.07.2017

Otrzymano: 17.05.2017 r.

Zaakceptowano: 4.07.2017 r.

439

How to cite this article

Dominiak M.P., Kłosek S.K., Gerlicz-Kowalczuk Z., Krzysiek J., Kobusiewicz A., Kaszuba K.: Bullous pemphigoid resembling erythema gyratum repens - case report. Dermatol Rev/Przegl Dermatol 2017, 104, 439-445.

DOI: https://doi.org/10.5114/dr.2017.69769. 